\title{
Fire prevention in vegetation in paleontological areas of the \\ Rio do Peixe region - PB
}

\author{
Francisco Fredson de Sousa ${ }^{1 *}$, Charlton Ribeiro de Santana ${ }^{1 * *}$, Leonardo Guimarães da Penha ${ }^{1 * * *}$
}

${ }^{1}$ Corpo de Bombeiros Militar da Paraíba (CBMPB), Paraíba, Brasil

E-mail para contato:*ffredson3000@gmail.com; ** charltonribeiro@gmail.com;

***1eoguimaraes19@gmail.com

\begin{abstract}
The interior region of the State of Paraíba, where the cities of Sousa and Uiraúna are part, have two Cretaceous basins that make up the Rio do Peixe, possessing a historical heritage with several dinosaur footprints. These basins are located in the Northeast of Brazil and its origins are related to the movements of failures occurring in the along the opening of the Atlantic Ocean. Therefore, the area of fossil footprints demarcated from greatest importance is distributed in the region of Passagem das Pedras, in the municipality of Sousa, where it currently houses a natural park denominated the Monumento Natural Vale dos Dinosaurs, with 40 hectares of area with ichnofossiliferous wealth. Otherwise, this area presents many threats of degradation through the anthropic action of fires by scarcity of effective actions for conservation and protection. In this sense, the present work aimed to carry out strategic planning for preservation against fire in vegetation in a paleontological and geological area of the Sousa and Uiraúna basins. The management of these activities was developed by the unit of the $6^{\circ}$ Batalhão do Corpo de Bombeiros Militar da Paraíba (6th BBM), through the monitoring of important areas, demarcation, mapping, basin analysis and monitoring. In view of the above, the present work resulted in the creation strategies for preventing and combating fire in vegetation in demarcated geological sites. Through this work it is concluded that, using the necessary tools to conservation of paleontological heritage it is possible to achieve a reduction in destructive actions and degrading to these environments.
\end{abstract}

Keywords: conservation and protection; vegetation fire; geological sites; Valley of Dinosaurs 